A N N A L ES

UNIVERSITATIS MARIAE CURIE-SKŁODOWSKA

LUBLIN - POLONIA

VOL. LXIV, 2

SECTIO G

2017

Uniwersytet Opolski

mpszczynski@uni.opole.pl

\title{
MATEUSZ PSZCZYŃSKI
}

\section{Trzy modele reform administracji publicznej a legitymizacja służby publicznej}

Three Models of Public Administration Reform and the Legitimacy of Civil Service

Obywatelska akceptacja prawa państwa do rządzenia słabnie coraz bardziej. Kryzys legitymacji władzy publicznej jest widoczny zarówno w strukturach państwowych, jak i ponadpaństwowych, czego przykładem jest Unia Europejska. Rządzący, by utrzymać się u władzy, starają się zabiegać permanentnie o potwierdzanie swej pozycji. Dla pełnej legitymizacji aktorów publicznych istotne jest przekonanie rządzonych, że dana grupa polityczna jest prawomocnie wyłoniona do pełnienia funkcji, a podejmowane przez nią działania są ważne i legalne. Ostatnio odwoływanie się do legalnych procedur wyłaniania władzy nie wystarcza, a uprawnienia do radykalnych zmian prawa i instytucji publicznych są podważane.

Do głosu dochodzą argumenty wskazujące na fakt legitymizacji władzy przez działania respektujące wartości wyznawane przez społeczeństwo. Zakres działania władzy publicznej, zwłaszcza w sferze administracji świadczącej, jest ważny dla społeczeństw demokratycznych. Reformy administracji publicznej, podejmowane w duchu new public management (NPM) czy governance, nie do końca są akceptowane przez społeczeństwo, zwłaszcza gdy zostały zredukowane zadania do tej pory realizowane. Wyznawana aksjologia realizowana przez sprywatyzowaną administrację publiczną oraz traktowanie obywatela jako konsumenta istotnie podważają zaufanie do władzy politycznej oraz administracji publicznej. Należy się zatem zastanowić, jakie wartości - z punktu widzenia administracji publicznej rozumianej jako służba publiczna, służenie społeczeństwu - są akceptowane i mogą się przyczynić do wzrostu legitymizacji państwa i jego organów. Poboczną kwestią jest pozycja służby publicznej w koncepcjach new public management, new public governance (NPG) oraz neo-Weberian state (NWS), 
ponieważ te trzy modele reform administracji są wiodące w ostatnich reformach struktur i procesów sektora publicznego.

New public management jest zespołem koncepcji bazujących na teorii zarządzania oraz teorii instytucjonalnej. Główny nacisk kładzie się tu na efektywność sektora publicznego, przekazanie struktur, konkurencję, techniki menadżerskie oraz wzrost kontraktowania zadań publicznych na zewnątrz administracji. Jednocześnie realizacja reform $\mathrm{w}$ duchu NPM doprowadziła do decentralizacji, bowiem kierownicy mieli się stać autonomicznymi menadżerami sprawującymi pełnię władzy. W praktyce, jak podnosi P. Lægreid, wszędzie, gdzie wprowadzano reformy menadżerskie, skutkowały one horyzontalną i wertykalną specjalizacją, co z kolei powodowało fragmentaryzację sektora publicznego ${ }^{1}$. Przy okazji należy dodać, że w krajach Europy Środkowo-Wschodniej dużą wagę przykładano do prywatyzacji zadań i struktur pierwotnie należących do państwa. W głównej mierze zmiany były przeprowadzane $\mathrm{w}$ administracji świadczącej, a w mniejszym stopniu w administracji regulującej, choć istniał szeroki trend deregulacji rynków, a więc częściowego wycofania się państwa z gospodarki.

W koncepcjach NPM wyraźnie wskazuje się na wprowadzenie metod zarządzania i rozliczania administracji przejętych z sektora prywatnego. Standaryzacja pracy, rozliczanie przez wyniki, kultura korporacyjna oraz współzawodnictwo wewnątrz organizacji silnie odcisnęly swe piętno na wielu podmiotach publicznych. Mocne urynkowienie skutkowało również przyjęciem idei, że administracja publiczna ma sprawnie, efektywnie wykonywać swe zadania, a nierentowne czy mało opłacalne wypychać ze sfery publicznej. Tym samym realizacja zadań publicznych najbardziej interesujących obywatela odeszła do lamusa. Nie ma obywatela, jest za to klient - żądający i oczekujący sprawnego, szybkiego załatwienia swojej sprawy. Wykonywanie usług publicznych zaczęło odbywać się już nie w oparciu o prawo administracyjne, lecz normy prawa cywilnego. Tymczasem urynkowienie usług publicznych, wbicie ich w gorset cywilistyczny sprawia, że nabierają one innego charakteru także w sferze finansowej. Jeśli podatki nie wystarczają na pokrycie kosztów zadań publicznych, żąda się dopłat ze strony beneficjentów, a w skrajnych przypadkach zaprzestaje się realizacji zadania publicznego. Urynkowienie administracji publicznej, konkurencja wewnątrz administracji oraz z otoczeniem, dopłacanie do usługi publicznej przez jej odbiorców, a także akcentowanie ekonomicznych aspektów realizacji zadań publicznych zmienia optykę na administrację publiczną i jej rolę, a tym samym rolę państwa. Osłabia pozycję obywatela, który staje się klientem przynoszącym zysk. W ten sposób państwo przestaje się różnić od rynku, a zatem powstaje pytanie: po co państwo w takiej formie? Zbytnie urynkowienie i prywatyzacja zadań publicznych deza-

1 T. Christensen, P. Lægreid, Transcending New Public Management. The Transformation of Public Sector Reforms, Aldershot 2009, s. 8. 
wuują rolę urzędnika, jaką pełnił do tej pory. Zdarza się, że urzędnik, dotychczas publiczny, jest pracownikiem prywatnego podmiotu realizującego zadanie publiczne w oparciu o kontrakt. Tym samym identyfikuje się z celami organizacji, w której wykonuje pracę, a nie z celami i wartościami publicznymi. Poza tym dochodzi jeszcze kwestia działania od projektu do projektu, a więc brak stabilizacji w realizacji konkretnego działania oraz konkretnego celu. Te wszystkie wyżej wymienione elementy, ważkie na wolnym, wysoko konkurencyjnym rynku, zawodzą w działaniach administracji publicznej, ponieważ państwo powinno mieć jeden cel - realizację interesu publicznego, a nie osiąganie zysku za wszelką cenę.

Krytyka teorii, a zwłaszcza praktyki NPM, stała się podstawą do wykreowania nowej koncepcji reform administracji publicznej. Wskazywała ona na istotną rolę adresatów działań administracji, zaangażowanie ich w procesy publiczne i stworzenie warunków do sieciowej administracji publicznej. O ile NPM wywodziła się z teorii ekonomicznych, o tyle NPG ma swe korzenie w koncepcjach socjologicznych. W myśl tej koncepcji obywatel nie jest tylko klientem, lecz jest interesariuszem, tzn. podmiotem będącym celem działania administracji publicznej. Jednocześnie przyznano mu wiodącą rolę w definiowaniu pól działania administracji publicznej. W ramach wspólnej sieci podmiotów administracja publiczna, partnerzy społeczni i obywatele wspólnie rozwiązują problemy społeczne lub na nowo określają cele społeczne, które mają być realizowane przez państwo i jego administrację.

Mnogość podmiotów działających w sferze publicznej tworzy sieć powiązań, które pozwalają realizować cele publiczne. Administracja publiczna, grupy interesu, organizacje społeczne oraz przedsiębiorcy współdziałają, ale również konkurują ze sobą, bowiem każdy z nich realizuje swe własne cele. Jak pisze E. Loffler, nie ma jednego, wystarczająco silnego aktora, który mógłby przejąć polityczne rezultaty tylko dla siebie ${ }^{2}$. Gracze są nastawieni na procesy polityczne, które pozwolą osiągnąć cele społeczne, a nie tylko ekonomiczne. Organizacje społeczne i przedsiębiorcy realizujący zadania publiczne nie działają tylko jako podwykonawcy czy zleceniobiorcy administracji publicznej, ale również aktywnie angażują się, czując się odpowiedzialnymi za zlecone zadanie. Co więcej, koalicje optujące za jakimś celem czy realizujące zadania publiczne zawiązują się ad hoc - do konkretnego działania czy projektu, by przy kolejnym konkurować między sobą.

W koncepcji NPG nastąpiło istotne, w stosunku do NPM, przedefiniowanie roli obywatela, odejście od traktowania go jako zwykłego klienta sfery publicznej. Jest on włączany w działania publiczne. Zwiększyła się jego rola jako uczestnika procesów decyzyjnych oraz jako odbiorcy działań funkcjonariuszy publicznych. Można powiedzieć, że koncepcja new public governance pozwoliła

2 E. Loofler, Governance: Network with stakeholders, [w:] T. Bovaird, E. Loffler, Public Management and Governance, London-New York 2007, s. 170. 
stworzyć konstrukcję państwa partycypacyjnego, w której obywatel nie dokonuje wyboru działań i aktywności państwa w systemie głosowania raz na kilka lat, lecz aktywnie współdecyduje o wszelkich zmianach. Stąd cała gama instrumentów prawnych pozwalających na partycypacje: od budżetu obywatelskiego, przez opiniowanie, konsultacje społeczne, wysłuchania publiczne, ewaluację działań sieci sfery publicznej, po rady dzielnic i osiedli czy zespoły wybierające konkretne cele publiczne lub sposób ich realizacji. Szeroka partycypacja obywateli i podmiotów społecznych w działaniach państwa zwiększyła zarazem odpowiedzialność wszystkich aktorów życia publicznego za osiągnięcie celu. Rola obywateli w życiu publicznym, w świetle koncepcji governance, nie jest iluzoryczna. Równocześnie niedopuszczalne jest, by państwo fasadowo traktowało graczy lub ograniczało ich uprawnienia w kreowaniu polityki publicznej. Wysoki stopień zaangażowania obywateli w procesy decyzyjne wzmacnia akceptację i zaufanie do państwa, uwiarygadnia działania przez nie podjęte.

W modelu NPG pracownik publiczny jest menadżerem, podobnie jak w świetle koncepcji NPM. Społeczna odpowiedzialność (w modelu NPG), realizacja celów w ramach sieci, a więc leżących poza organizacją, w której działa, a zwłaszcza dążenie do osiągnięcia interesu publicznego zdefiniowanego w drodze negocjacji i konsensusu, zmienia w pewnym stopniu optykę służby publicznej. Jednakże kontraktowanie usług publicznych, działania projektowe, menadżerski sposób zarządzania wewnątrz i szczególnie oceny pracowników powodują, że wady dostrzegane w NPM nie zostały wyeliminowane.

W opozycji do NPM powstała na kontynencie europejskim koncepcja neo-Weberian state (NWS). Dotychczasowe doświadczenia NPM oraz NPG pokazały istotne zalety, ale również szereg wad, które nałożyły się na funkcjonowanie i organizację współczesnej biurokracji. Z kolei zaproponowana przez C. Pollitta i G. Bouckaerta w $2004 \mathrm{r}^{3}$ koncepcja neo-Weberian state zakłada, że służby publiczne mają być bardziej profesjonalne, bardziej efektywne i przyjacielsko nastawione do obywateli. Nie odrzucono jednak neoliberalnych metod menadżerskich, chociaż przynano im status subsydiarny. Państwo działa według własnych zasad, posługując się swoistymi metodami, zwłaszcza prawnymi. Przy stosowaniu tej koncepcji następuje powrót do idei silnego państwa, jego afirmacja jako jedynego podmiotu, który jest w stanie funkcjonować w erze globalizacji, terroryzmu, kataklizmów czy zmian demograficznych ${ }^{4}$. Powrót ten skutkuje odejściem od szerokiej partycypacji obywatelskiej oraz wskazaniem modelu przedstawicielskiego jako podstawowego przy podejmowaniu decyzji czy definiowaniu celów publicznych, co stawia tę ideę w opozycji do NPG.

3 C. Pollitt, G. Bouckaert, Public Management Reform: A Comparative Analysis - New Public Management, Governance, and the Neo-Weberian State, Oxford 2011, s. 19.

4 Ibidem, s. 118. 
Sam termin neo-Weberian nie jest nowy, gdyż - jak podnosi L.E. Lynn przynajmniej od lat 70. XX w. używano go w literaturze socjologicznej i naukach o administracji w nawiązaniu do „machinerii rządzenia” czy relacji w systemie politycznym ${ }^{5}$. W ujęciu współczesnym element Weberian należy odnieść do zhierarchizowanej administracji publicznej rządzącej się prawem. Przedrostek neowskazuje na elementy skierowane w stronę obywatela (identyfikację jego potrzeb) oraz szerszą odpowiedzialność i przejrzystość działań administracji publicznej. W państwie neoweberowskim prawo ma mieć decydujący wpływ na ramy kształtujące społeczeństwo i relacje między państwem a obywatelami.

Elastyczność administracji publicznej, tak aprobowana w NPM, powinna być zastąpiona przez stabilizację, jaką cechują się publiczne podmioty, ze swą hierarchiczną strukturą oraz zasadami i wartościami. Jednocześnie przy takim rozwiązaniu nastąpi odejście od deregulacji i powszechnej prywatyzacji na rzecz przewidywalnego prawa (zwłaszcza prawa administracyjnego) w relacjach państwo - obywatel. Odstąpienie od koncepcji NPM na rzecz NWS doprowadzi do realizacji zadań publicznych przez podmioty publiczne, a nie przez rynek i wolną konkurencję. Jak podnosi T. Randma-Liiv, jest to kierunek szczególnie istotny w państwach Europy Środkowo-Wschodniej, w których słaba władza publiczna nie poradziła sobie $\mathrm{z}$ graczami rynkowymi, ponieważ nie była $\mathrm{w}$ stanie ich skutecznie kontrolować6.

Wskazane elementy wprost odnoszą się do koncepcji M. Webera, czy to w afirmacji roli państwa, jego hierarchicznej struktury, czy roli prawa publicznego w rozwiązywaniu problemów społecznych. Wśród neo wymienia się wzmocnienie procesów demokracji przedstawicielskiej, zarządzanie zasobami przez państwo oraz tworzenie swoistej kultury podczas realizacji zadań publicznych.

Powrót do koncepcji weberowskich oraz wykorzystanie doświadczeń poprzednich nurtów reform administracji publicznej spowodował postawienie na nowo pytań o służbę publiczną: jaką rolę ma pełnić w państwie, jaka ma być rola urzędników publicznych. Odpowiedzi należy szukać w profesjonalizacji służb publicznych, gdzie urzędnicy będą nie tylko ekspertami w stosowaniu prawa, ale również profesjonalnymi menadżerami potrafiącymi identyfikować potrzeby obywateli ${ }^{7}$. Podejmowane zmiany mają skutkować wzrostem zaufania do biurokracji wraz z jej profesjonalizacją, a tym samym przekładać się na legitymizację administracji publicznej. Wśród personelu publicznego należy promować zmiany kultury administrowania w celu wytworzenia wysokiej jakości służby publicznej.

5 L.E. Lynn, What is a Neo-Weberian State? Reflections on a Concept and its Implications, www.researchgate.net/publication/268398484_What_Is_a_Neo-Weberian_State_Reflections on_a_Concept_and_Its_Implications [dostęp: 10.11.2017].

6 T. Randma-Liiv, New Public Management versus Neo-Weberian State in Central and Eastern Europe, "The NISPAcee Journal of Public Administration and Policy" 2008, No. 1.

7 C. Pollitt, Geert Bouckaert, op. cit., s. 119. 
Stabilizacja zatrudnienia (w przeciwieństwie do elastycznych form stosowanych w organizacjach społecznych czy zatrudnieniu w oparciu o kontrakt), połączona ze szczególnym statusem prawnym, odrębny i motywacyjny system płac oraz wartości etyczne mają przyczyniać się do wzrostu atrakcyjności zatrudnienia w administracji publicznej. Jeśli do tego dodamy wewnętrzną motywację pracowników publicznych oraz etos moralny, to duch Webera wróci do współczesnej administracji publicznej. Takie neoweberowskie podejście do zmian w administracji jest mieszanką empirycznych doświadczeń oraz normatywnych elementów przekładających się na ideę nowoczesnej służby publicznej ${ }^{8}$. Nie jest to tylko hierarchia, ale też pewne elementy reform NPM czy NPG, które w jakimś zakresie się sprawdziły lub pasują do współczesnego państwa.

Jak wskazano wyżej, administracja publiczna podlega permanentnym reformom. Trzy przywołane koncepcje kształtują dosyć istotnie współczesną administrację. Oczywiście państwa zachodnie (jak USA, Nowa Zelandia) czy państwa skandynawskie inaczej przeszły etap NPM, odmiennie od krajów postkomunistycznych. Podobne zróżnicowanie nastąpiło przy wprowadzaniu idei governan$c e \mathrm{w}$ państwach o wysokim kapitale społecznym i tych o niskim jego poziomie. Jednakże w przypadku większości krajów demokratycznych wspomniane modele reformowania administracji publicznej odcisnęły trwałe piętno na funkcjonowaniu służb publicznych.

Pozycja służby publicznej znacznie różni się w trzech przedstawionych modelach reform administracji publicznej. W modelu NPM wystepują samodzielni menadżerowie rozliczani w oparciu o wyniki, działający w konkurencyjnym środowisku. W modelu NPG mamy do czynienia z siecią menadżerów, negocjujących i szukających wpływu oraz synergii w podejmowanych działaniach. Natomiast w modelu NWS służba cywilna wprowadza w życie zarówno prawo, jak i decyzje polityków. Składa się ona z technicznych ekspertów realizujących na wysokim poziomie usługi publiczne w oparciu o kod etyczny. Jak widać, te trzy modele charakteryzują się innym spojrzeniem na służbę publiczną i jej rolę we współczesnym państwie.

Reformy są przeprowadzane między innymi po to, by usprawnić działanie administracji publicznej, wzmocnić jej pozycję w społeczeństwie, uwiarygodnić działania służb publicznych oraz zwiększyć legitymizację podmiotów publicznych. $Z$ uwagi na fakt, iż legitymizacja jest rozumiana różnorako, należy dokonać oceny, czy i w jakim stopniu modele reform korelują z legitymizacją służby publicznej oraz przyjąć wstępne założenia związane z tą konstrukcją.

Tradycyjne rozumienie legitymizacji wywodzone jest, nomen omen, od Webera. Twierdził on, że władza panuje legalnie na mocy ustanowienia. Wła-

8 The Civil Service in the 21 $1^{\text {st }}$ Century: Comparative Perspectives, eds. J. Raadschelders, T. Toonen, F. Van der Meer, Frits M. Van der Meer, London 2007, DOI: https://doi.org/10.1057/ 9780230593084, s. 312. 
dza biurokratyczna może tworzyć i zmieniać dowolne prawa, o ile dokonuje tego za pomocą formalnie prawidłowego prawodawstwa9 . Legitymizacja wiąże się z przeświadczeniem ludzi, obywateli do uprawnionego użycia siły przez władzę, która je wywodzi ze stanowionego przez siebie prawa. Uzupełnieniem tej koncepcji jest demokratyczny mandat władzy, tzn. władza ma prawo do tworzenia prawa i stosowania przemocy, o ile uzyskała tę władzę w oparciu o prawnie określone, demokratyczne procedury. Tym samym mówimy o panowaniu legalnym w znaczeniu proceduralnym.

W nawiązaniu do F.W. Scharpfa ${ }^{10}$ można przyjąć, że demokratyczna legitymizacja ma charakter input (proceduralny) oraz output (wynikowy). Pierwszy dotyczy procedur lub mechanizmów, które pozwalają grupie uzyskać władzę lub prawo do podjęcia politycznej decyzji. Najczęściej jest to mandat demokratyczny, uzyskany w drodze legalnych wyborów, ale również w procedurze nie do końca demokratycznej, byleby akceptowanej przez obywateli. Drugi obejmuje wynik działania władzy legalnej, ponieważ władza jest akceptowana za swoje wyniki. Można też przyjąć, że jeśli władza zaspokaja potrzeby obywateli, to ma szanse na dużą legitymizację swych działań. Jeśli rządzący nie zyskują akceptacji dotychczasowej aktywności, to kolejne wybory input odbiorą im władzę.

Jak pisze C. McLoughlin ${ }^{11}$, legitymizacja typu otuput mieści się w weberowskiej kategorii legitymizacji prawno-racjonalnej, wynikającej nie z charyzmy czy z tradycji, lecz z funkcjonowania instytucji, w tym wypadku służby publicznej. W tym też, jak się wydaje, należałoby poszukiwać głównego elementu legitymizującego działanie służb publicznych. Jednakże nie można sprowadzić działań administracji publicznej, polegających na świadczeniu usług publicznych akceptowanych i oczekiwanych przez obywateli, do podstawowego elementu legitymizującego działanie służb publicznych. Nie da się wskazać konkretnego zadania publicznego, którego realizacja wpływa na legitymizację bądź delegitymizację, gdyż proces ten jest bardziej skomplikowany - obejmuje np. prawo czy aksjologię państwa. Co prawda, McLoughlin podnosi, że nie ma istotnego związku między udzielaniem świadczeń publicznych a legitymizacją państwa, jednak wskazuje, że świadczenie usług publicznych może być analizowane zarówno jako źródło procesu legitymizacji procesowej, jak i legitymizacji normatywnej. W tym pierwszym aspekcie rezultat aktywności służb publicznych ma charakter instru-

9 W. Wesołowski, Weberowska koncepcja legitymizacji: ograniczenia i kontynuacje, [w:] Legitymacja: klasyczne teorie i polskie doświadczenia, red. A. Rychard, Warszawa 1988, s. 47.

10 F.W. Scharpf, Economic integration, democracy and the welfare state, "Journal of European Public Policy" 1997, Vol. 4(1), DOI: https://doi.org/10.1080/135017697344217.

11 C. McLoughlin, When Does Service Delivery Improve the Legitimacy of a Fragile or Conflict-Affected State?, "Governance: An International Journal of Policy, Administration, and Institutions" 2015, Vol. 28(3), DOI: https://doi.org/10.1111/gove.12091. 
mentalny ${ }^{12}$, a zatem nie bezpośrednio, ponieważ to sposób i poziom świadczeń publicznych może wpływać na stopień legitymizacji działań służby publicznej. Niewątpliwie charakter modelu administracji publicznej będzie miał tu kluczowe znaczenie.

Służba publiczna, dostarczając usługi publiczne, w każdym z trzech wyżej przedstawionych modeli reform ma inny kształt, inne zadania, w odmienny sposób jest rozliczana oraz - co wydaje się najważniejsze - działa w oparciu o inne wartości. W nurcie menadżerskim nacisk kładzie się na konkurencję, elastyczność kadr, zarządzanie przez wyniki czy szukanie zysku. Tak przyjęty model niewątpliwie budzi wątpliwości, czy do wszystkich sfer aktywności administracji świadczącej da się zastosować standard finansowy w postaci niższych kosztów czy nawet zysku. Widać wyraźnie, zwłaszcza w oświacie czy opiece medycznej, że typowo menadżerskie i finansowe podejście nie spotyka się z akceptacją społeczeństwa, zarówno tą wyrażaną w drodze opinii, jak i przez czyny, gdyż wielu przedsiębiorców stara się minimalizować składkę zdrowotną, korzystając (w razie potrzeby) z prywatnej służby zdrowia. Jest to finansowy wyraz dezaprobaty dla przyjętego menadżerskiego modelu świadczenia usług publicznych, a tym samym swego rodzaju słabsza legitymizacja typu output. W tym przypadku może również wystąpić delegitymizacja typu input, bowiem adresat usługi może uznać, że państwo i jego urzędnicy nie wykonują swoich obowiązków wynikających z prawa, a tym samym prawa obywatelskie nie są w pełni realizowane czy chronione.

$\mathrm{Z}$ drugiej strony propozycja zarysowana w koncepcji NPG, dotycząca szerokich konsultacji, deliberacji i partycypacji obywatelskiej, spotkała się w pewnych kręgach (kulturowych, społecznych, edukacyjnych, finansowych) z szeroką akceptacją dla tego typu działań. Aktywne uczestnictwo pewnych grup społecznych w partycypacji może przełożyć się na zwiększenie aprobaty działań podjętych przez służby publiczne. Co więcej, skoro ktoś uczestniczył w procesie wybierania celu publicznego czy tworzenia prawa, niewątpliwie rzadziej będzie naruszał przepisy i częściej będzie stosował się do norm, które współtworzył. Mamy zatem do czynienia z legitymizacją zarówno na poziomie input, jak i output, tak w sensie normatywnym, jak i procesowym.

Niewątpliwie wzmocnienie roli służby publicznej w państwie, proponowane w modelu NWS, samo w sobie najbardziej przyczynia się do zwiększenia stopnia jej legitymizacji. Skoro będziemy mieli profesjonalną służbę publiczną, konsekwentnie realizującą prawo, to jest szansa na zwiększenie stopnia legitymizacji już nie tylko czysto normatywnej, ale i procesowej.

Ważnym elementem, zwłaszcza w legitymizacji działania państwa i jego służby publicznej, są wartości deklarowane i realizowane przez przedstawicieli

12 Ibidem. 
publicznych. Uzyskanie władzy w sposób legalny, zgodnie z obowiązującymi normami, nie upoważnia do działania wbrew wartościom aprobowanym w społeczeństwie. W przypadku rażącego naruszenia tych wartości może dojść do delegitymizacji działań służby publicznej, a w dalszym etapie - państwa. Zmiana modelu administracji publicznej i realizowanych przez nią zadań musi być akceptowana przez społeczeństwo, by uzyskać choć elementarny poziom legitymizacji działań.

\section{BIBLIOGRAFIA}

Christensen T., Lægreid P., Transcending New Public Management. The Transformation of Public Sector Reforms, Aldershot 2009.

Loffler E., Governance: Network with stakeholders, [w:] T. Bovaird, E. Loffler, Public Management and Governance, London-New York 2007.

Lynn L.E., What is a Neo-Weberian State? Reflections on a Concept and its Implications, www.researchgate.net/publication/268398484_What_Is_a_Neo-Weberian_State_Reflections_on_a_ Concept_and_Its_Implications [dostęp: 10.11.2017].

McLoughlin C., When Does Service Delivery Improve the Legitimacy of a Fragile or ConflictAffected State?, "Governance: An International Journal of Policy, Administration, and Institutions" 2015, Vol. 28(3), DOI: https://doi.org/10.1111/gove.12091.

Pollitt C., Bouckaert G., Public Management Reform: A Comparative Analysis - New Public Management, Governance, and the Neo-Weberian State, Oxford 2011.

Randma-Liiv T., New Public Management versus Neo-Weberian State in Central and Eastern Europe, "The NISPAcee Journal of Public Administration and Policy" 2008, No. 1.

Scharpf F.W., Economic integration, democracy and the welfare state, "Journal of European Public Policy" 1997, Vol. 4(1), DOI: https://doi.org/10.1080/135017697344217.

The Civil Service in the $21^{\text {st }}$ Century: Comparative Perspectives, eds. J. Raadschelders, T. Toonen, F. Van der Meer, Frits M. Van der Meer, London 2007, DOI: https://doi.org/10.1057/9780230593084.

Wesołowski W., Weberowska koncepcja legitymizacji: ograniczenia i kontynuacje, [w:] Legitymacja: klasyczne teorie i polskie doświadczenia, red. A. Rychard, Warszawa 1988.

\section{SUMMARY}

Public administration is subject to permanent reforms, adapting its organization, tasks, approach to the needs and ideas of the modern world. At the same time, looking for the elements and forms that legitimize its functioning. Introduced reforms change the role and position of the civil service, affecting its legitimacy. Executive Management Model NPM affects the range of public benefits, and thus, indirectly, acceptance of a new model of public service. NPG model strengthens the position of the citizen in the process of setting public purpose, forces civil service to the negotiations, consensual activities while defining the public interest. In this way, a citizen deciding together with the public administration, accepts the public service activities and, at the same time, legitimizes them. The affirmation of the public service and its role in the performance of state tasks strengthens its position in the state and, thus, indirectly influences the legitimacy level of the civil service.

Keywords: new public governance; new public management; neo-Weberian state; legitimization; civil service 


\section{STRESZCZENIE}

Administracja publiczna podlega permanentnym reformom, dostosowując swoją organizację, zadania i sposób działania do potrzeb oraz idei współczesnego świata. Jednocześnie szuka elementów i form legitymizujących jej funkcjonowanie. Wprowadzane reformy zmieniają rolę i pozycję służby publicznej, oddziałując na jej legitymizację. Menadżerskie zarządzanie z modelu NPM wpływa na zakres świadczeń publicznych, a tym samym (nie wprost) na akceptację nowego modelu służby publicznej. Z kolei model NPG wzmacnia pozycję obywatela w procesie wyznaczania celu publicznego, zmusza służbę publiczną do negocjacji i działań konsensualnych w czasie definiowania interesu publicznego. W ten sposób obywatel, decydując wraz z administracją publiczną, akceptuje działania służby publicznej i jednocześnie je legitymizuje. Afirmacja służby publicznej i jej roli w realizacji zadań państwa wzmacnia jej pozycję w państwie, a tym samym pośrednio wpływa na poziom legitymizacji służby publicznej.

Slowa kluczowe: new public governance; new public management; państwo neoweberowskie; legitymizacja; służba publiczna 